\title{
An Electrochemical Immunoassay for HER2 Detection
}

\author{
Q A M Al-Khafaji, M Harris, S Tombelli, S Laschi, Anthony Turner, \\ M Mascini and G Marrazza
}

\section{Linköping University Post Print}

N.B.: When citing this work, cite the original article.

This is the authors' version of the original publication:

Q A M Al-Khafaji, M Harris, S Tombelli, S Laschi, Anthony Turner, M Mascini and G Marrazza, An Electrochemical Immunoassay for HER2 Detection, 2012, Electroanalysis, (24), 4, 735-742.

http://dx.doi.org/10.1002/elan.201100501

Copyright: Wiley-VCH Verlag Berlin http://www.wiley-vch.de/publish/en/

Postprint available at: Linköping University Electronic Press

http://urn.kb.se/resolve?urn=urn:nbn:se:liu:diva-76937 


\title{
AN ELECTROCHEMICAL IMMUNOASSAY FOR HER2 DETECTION
}

\author{
Q.A.M. AL-KHAFAJI ${ }^{\mathrm{a}, \mathrm{b}}$, M. HARRIS ${ }^{\mathrm{a}, \mathrm{c}}$, S. TOMBELLI ${ }^{\mathrm{a}}$, S. LASCHI ${ }^{\mathrm{a}}$, APF TURNER ${ }^{\mathrm{c}, \mathrm{d}}, \mathrm{M}$. \\ MASCINI $^{\mathrm{a}}$, G. MARRAZZA ${ }^{\mathrm{a}}$
}

${ }^{a}$ Dipartimento di Chimica Ugo Schiff, Università degli Studi di Firenze, Italy

${ }^{\mathrm{b}}$ Al-Nahrain Medical College, Baghdad, Iraq; Kamal Al-Samaraei Hospital for IVF and Infertility, Baghdad, Iraq

${ }^{\mathrm{c}}$ Cranfield Health, Cranfield University, UK

${ }^{\mathrm{d}}$ Biosensors \& Bioelectronics Centre, IFM-Linköping University, Sweden

\begin{abstract}
In this paper, a simple and sensitive approach for human epidermal growth factor receptor 2 (HER2) detection is presented, using antibody-functionalised magnetic beads coupled to screenprinted cells. The immunoassay is based on a sandwich format in which a primary monoclonal antibody anti-HER2 is coupled to protein A modified magnetic beads. The modified beads are then used to capture the protein from the sample solution and a sandwich assay is performed by adding a secondary monoclonal antibody anti-HER2 labelled with biotin. The enzyme alkaline phosphatase (AP) conjugated with streptavidin and its substrate (1-naphthyl-phosphate) are then used for the electrochemical detection by differential pulse voltammetry (DPV). The experimental conditions for the immunoassay were optimised. The performance of the assay in terms of sensitivity, reproducibility and selectivity has been studied in buffer and serum samples.
\end{abstract}

Keywords: HER2, cancer marker, beads, immunoassay

*Corresponding author: tel. +39055 4573320, fax +39 055 4573396, e-mail:

giovanna.marrazza@unifi.it 


\section{Introduction}

The development of immunosensors for the detection and monitoring of cancer markers is a major area of recent research.

The aim of the present work is the investigation of screening devices for the detection of human epidermal growth factor receptor 2 (HER2) cancer marker by using antibody-modified magnetic microparticles coupled to screen-printed electrochemical platforms.

Overexpression of HER2 is observed in 20-30\% of breast cancer cases and treatment using a monoclonal antibody (trastuzumab) to this molecule is now advocated (Gohring et al., 2010), but is only effective in patients that have excess receptor levels. This means that screening of those patients who are eligible is required before treatment can be administered. Other cancers, such as ovarian, stomach, pancreatic and prostate, have also been shown to exhibit increased expression of HER2 (Payne et al., 2000), (Quaranta et al., 2006).

HER2 is a receptor tyrosine kinase, which belongs to the epidermal growth factor receptor (EGFR) family involved in cellular signalling pathways, that may lead to proliferation, growth, apoptosis and differentiation (Tse et al., 2005). These processes are essential to life, but loss of control within these pathways is frequently associated with disease including cancer.

The HER2 gene is located on chromosome 17 and encodes for a $185 \mathrm{KDa}$ protein with three distinct domains; an extracellular region with similarities to other EGFRs, a transmembrane hydrophobic section, and an intracellular zone with tyrosine kinase activity. The extracellular domain (ECD) can be cleaved by matrix metalloproteases, which leads to increased phosphorylation of the tyrosine kinase region and therefore escalated levels of signalling. The cleaved ECD then enters into the blood stream and can be an indicator of increased expression of HER2, but also highlights raised levels of tyrosine kinase domain activation (Tse et al., 2005), (Quaranta et al., 2006). Increased levels of HER2 ECD in serum is associated with a poor prognosis, reduced therapeutic response and decreased survival chances and is observed in patients with highly aggressive breast tumours (Payne et al., 2000), (Esteva et al., 2005), (Ludovini et al., 2008).

Current diagnostic tests for HER2 involve analysis of tumour cells for either amplification of the HER2 gene using fluorescent in situ hybridisation (FISH) or immunohistochemistry (IHC) to determine the expression of the receptor within the cell membrane (Tse et al., 2005).

Both procedures are complex, involve time consuming steps and require specially trained personnel to carry out the procedures (Gohring et al., 2010). Paraffin embedded samples used in both IHC and FISH are collected via invasive biopsies and must be prepared correctly to minimise problems with interpretation (Lottner et al., 2005). 
Alternative methodologies are being researched that minimise the disadvantages of these techniques. Some of these procedures are variations on the existing tests (IHC and FISH) and involve the introduction of novel labelling practices such as chromogenic in situ hybridisation (CISH) (Cayre et al., 2007), fluorescence immunohistochemistry (FIHC) or a combination of both (Lottner et al., 2005). The use of real time polymerase chain reaction (QPCR) for the detection of the HER2 gene and enzyme linked immunosorbent assay (ELISA) for the detection of serum HER2 ECD have been investigated as quantitative alternatives to FISH and IHC and results show promise for the future.

There are data that indicate that the monitoring of the HER2 ECD as a real-time prognostic tool could be used to determine treatment efficiency and indicate that the patient remains disease free by comparing the serum level of HER2 from a pre-treatment baseline with measurements taken during and after treatment (Payne et al., 2000), (Streckfus et al., 2000), (Esteva et al., 2005). The measurement of serum HER2 ECD levels may also be useful following the removal of tumour tissue which would mean the material required for IHC and FISH would no longer be available (Payne et al., 2000). Patients with breast cancer have concentration of HER2 ECD in the blood of over $15 \mathrm{ng} \mathrm{mL}^{-1}$, whereas healthy individuals have levels below this value, therefore an assay must be able to measure to this concentration (Esteva et al., 2005), (Gohring et al., 2010). A study has also been conducted to investigate the potential to use measurements of HER2 ECD levels in saliva as an alternative to serum (Streckfus et al., 2000).

In this paper, the development of simple and rapid immunoassay for HER2 analysis in buffer and human serum is described. The proposed approach uses disposable screen-printed cells as transducers and a simple target capturing step by antibody-functionalised magnetic beads.

The assay is based on a sandwich format in which a primary monoclonal antibody anti-HER2 is coupled to protein A-modified magnetic beads. The modified beads are then used to capture the protein from the sample solution and the sandwich assay is performed by adding a secondary biotinylated polyclonal antibody anti-HER2. Streptavidin-alkaline phosphatase conjugated was then added to trace the affinity reaction. The enzymatic substrate, 1-naphthyl-phosphate, is then used for the electrochemical detection by Differential Pulse Voltammetry (DPV).

The performance of the assay in terms of sensitivity, reproducibility and selectivity in buffer and serum samples has been studied.

\section{Materials and Methods.}

\subsection{Chemicals and materials.}


Dynabeads ${ }^{\circledR}$ magnetic beads, coated with protein A, were provided by Invitrogen (Milan, Italy). Sodium phosphate dibasic dehydrate and sodium phosphate monobasic monohydrate were purchased from Merck (Milan, Italy). Sodium chloride, Trizma base, diethanolamine, magnesium chloride, potassium chloride, polyoxyethylene sorbitan monolaurate (Tween 20), bovine serum albumin, streptavidin-alkaline phosphatase conjugated, rabbit IgG (rIgG) and 1-naphthyl phosphate were obtained from Sigma (Milan, Italy). The protein HER2, the monoclonal antibody anti-HER2 (primary antibody) and the biotinylated polyclonal antibody anti-HER2 (secondary antibody) (R\&D Systems) were purchased from Space srl (Milan, Italy). The two anti-HER2 antibodies are recommended by the producer as antibody pair for HER2 sandwich assays as capture and detection antibody. All solutions were prepared using water from a Milli-Q Water Purification System (Millipore, UK). The sample mixer and magnet used to precipitate the beads out of solution were provided by Dynal Biotech (Milan, Italy).

Buffer solutions used and their composition:

- Buffer A: phosphate buffered saline (PBS) pH 7.4

- Buffer B: phosphate buffered saline (PBS) pH 7.4 with $0.05 \%$ w/w Tween 20

- Buffer C: Tris buffer 0.02 M pH 7.3 0.15 M NaCl

- Buffer D: Tris buffer $0.02 \mathrm{M} \mathrm{pH} 7.3$ with $0.05 \%$ Tween 20

- Buffer E: Diethanolamine buffer (DEA) $0.1 \mathrm{M} \mathrm{pH} 9.6$ with $1 \mathrm{mM} \mathrm{MgCl}_{2}$ and $0.1 \mathrm{M} \mathrm{KCl}$

- Buffer F: Diethanolamine buffer (DEA) 0.1 M pH 9.6 with 0.05\% Tween 20

- Buffer G: Diethanolamine buffer (DEA) $0.1 \mathrm{M} \mathrm{pH} 9.6$ with $1 \%$ bovine serum albumin (BSA)

Serum samples were kindly provided by AL-Kadhomyah Hospital (Baghdad, Iraq). The samples were from hospital patients who have been subjected to breast mass analysis: breast tissue samples were subjected to full histological diagnosis and DNA extraction for multiplex PCR testing. All the samples were from patient suffering from breast carcinoma, some with metastasis at different stages.

Commercial normal human serum (Sigma, Milan, Italy) was also used for the experiments.

\section{$2.2 \quad$ Screen-Printed Cells}

Screen printed cells, comprising of a carbon working and counter electrode and a silver reference electrode were used as the electrochemical cells. These were produced in house on a DEK 248 screen-printing machine (DEK, Weymouth, UK). The printing was performed on a polyester film (Autostat CT5) from Autotype (Milan, Italy) using the polymeric inks (Electrodag PF-410 (silver)) 
and (Electrodag 423 SS (graphite)), which were purchased from Acheson (Milan, Italy). Vinylfast 36-100 was used as the insulting ink and was obtained from Argon (Lodi, Italy). Differential Pulse Voltammetry (DPV) measurements were performed using a $\mu$ Autolab type II PGSTAT supported with GPES 4.9 software (Metrohm, Rome, Italy) using the following parameters; range potential 0/+600 mV, step potential $7 \mathrm{mV}$, modulation amplitude $70 \mathrm{mV}$, standby potential $200 \mathrm{mV}$, interval time 0.1 second.

\subsection{Scheme of the assay}

\subsubsection{Protein A-coated paramagnetic microparticles modified with rIgG anti-HER2}

In this work, a sandwich assay format was developed, and the steps are illustrated in Figure 1.

At this purpose, the stock solution of microbeads $\left(30 \mathrm{mg} \mathrm{mL}^{-1}\right)$ was re-homogenised in its original vial, then $0.100 \mathrm{~mL}$ of the suspension were taken by a pipette and added in a vial containing $0.4 \mathrm{~mL}$ of buffer A. The vial is then placed in a rotating stand for $2 \mathrm{~min}$ for washing. This procedure is repeated for three times. Between each washing step, the vial is removed and beads were captured using a magnetic particle concentrator (MagneSphere Magnetic Separation Stand, Promega) and resuspended in the same amount of fresh buffer B.

Once washing steps are terminated, microbeads were captured and added of $0.40 \mathrm{~mL}$ of monoclonal anti-human ErbB2 antibody (100 $\left.\mathrm{mg} \mathrm{L}^{-1}\right)$ was added and vortexed. The suspension was then incubated at room temperature for 40 minutes in the rotating stand. Thus, again microbeads were washed three times with buffer B following the washing procedure already reported.

The beads were then resuspended in $0.500 \mathrm{~mL}$ of buffer $\mathrm{C}$ and stored at $4{ }^{\circ} \mathrm{C}$ until required.

\subsubsection{Blocking with non-specific rabbit IgG}

In order to limit the nonspecific interaction between the assay reagents and the free sites eventually present onto the microbeads surface, after the beads functionalisation a blocking step was introduced. At this purpose, functionalised microbeads are incubated with $0.400 \mathrm{~mL}$ of buffer B containing 1,5 and $10 \mathrm{mg} \mathrm{L}^{-1}$ of $\mathrm{rgG}$ (i.e. which are not able to interact with the analyte) for 30 min under rotation. Then, microbeads are again washed three times with buffer $\mathrm{D}$ and buffer $\mathrm{C}$ and then reconstituted in $0.5 \mathrm{~mL}$ of the buffer $\mathrm{C}$.

\subsubsection{Reaction with antigen and with the secondary antibody}

To perform the calibration, $0.050 \mathrm{~mL}$ of functionalised bead suspension to $0.450 \mathrm{~mL}$ of buffer $\mathrm{C}$ were added, containing the antigen in order to have final HER2 concentrations in the range 0-30 ng 
$\mathrm{mL}^{-1}$. After an incubation time of $60 \mathrm{~min}$, beads were washed three times with $0.500 \mathrm{~mL}$ of buffer C.

Thus, $0.250 \mathrm{~mL}$ of solution of the secondary antibody at concentration $1 \mathrm{mg} \mathrm{L}^{-1}$, prepared in buffer $\mathrm{C}$, are added to the beads and left to incubate for $20 \mathrm{~min}$. Then, beads are washed three times in buffer C.

A negative control was also made to calculate the amount of background signal not caused by the immunocomplex.

The magnetic particles were then separated, as previously described, and two washes with buffer F were performed. The beads were then incubated with $0.500 \mathrm{ml}$ of steptavidin-alkaline phosphatase conjugated (3.9 $\left.\mathrm{U} \mathrm{mL}^{-1}\right)$ diluted in buffer $\mathrm{G}$ for ten minutes on the sample mixer. Each set of beads containing the immunocomplex was then washed twice after separation of the beads from the solution with buffer F. Finally the samples were resuspended in $0.050 \mathrm{ml}$ of buffer $\mathrm{E}$ and vortexed.

\subsubsection{Measurement with Screen-Printed Cell}

The screen printed cells were secured to a magnetic bar to ensure the retention of the beads and $0.010 \mathrm{~mL}$ of a sample was placed onto the working electrode, followed by the addition of $0.060 \mathrm{~mL}$ of a solution containing $1 \mathrm{mg} \mathrm{mL}^{-1} 1$-naphthyl phosphate prepared in buffer E. The measurement of current generated was taken 5 minutes after the addition of substrate using Differential Pulse Voltammetry.

\subsubsection{Analysis of serum samples}

When testing serum samples, $0.050 \mathrm{~mL}$ of functionalised beads suspension were mixed to $0.050 \mathrm{~mL}$ of undiluted serum and $0.400 \mathrm{~mL}$ of buffer C. After an incubation time of $60 \mathrm{~min}$, beads were washed three times with $0.500 \mathrm{~mL}$ of buffer $\mathrm{C}$ and further steps of incubation and measurements were repeated as reported form paragraph 2.2.3.

Experiments were also conducted on commercial normal human serum spiked with two concentrations of HER2 (15 $\mathrm{ng} \mathrm{mL}^{-1}$ and $\left.25 \mathrm{ng} \mathrm{mL}^{-1}\right)$. For these experiments $0.050 \mathrm{~mL}$ of functionalised beads suspension were mixed to $0.050 \mathrm{~mL}$ of undiluted serum and $0.400 \mathrm{~mL}$ of buffer $\mathrm{C}$ containing HER2 antigen in order to have HER2 concentration in the final volume of 15 and $5 \mathrm{ng} \mathrm{mL}^{-1}$. 


\section{Results and discussion}

The sandwich assay was optimised with respect to several parameters such as concentration of primary and secondary antibodies, incubation time of antigen and secondary antibody, blocking agent.

\subsection{Optimisation of the assay parameters}

As first point, procedures for beads functionalisation and conjugation with the antigen were optimised.

At this purpose, sandwich assays were carried out by varying one parameter per time, in order to experimentally establish the best parameter. The optimised parameters were primary antibody concentration, antigen incubation time and secondary antibody concentration and incubation time. All the parameters were tested by measuring HER2 at 0 and $10 \mathrm{ng} \mathrm{mL}^{-1}(\mathrm{n}=3)$. The results are reported in Table 1. In the table we report the average coefficient of variation (CV\%) for the two concentration of HER2 $\left(0\right.$ and $\left.10 \mathrm{ng} \mathrm{mL}^{-1}\right)$ and the signal ratio between the $10 \mathrm{ng} \mathrm{mL}^{-1}$ of HER2 and the blank ( $0 \mathrm{ng} \mathrm{mL} \mathrm{m}^{-1}$ of HER2). The best parameters were chosen considering the best discrimination between $10 \mathrm{ng} \mathrm{mL}^{-1}$ HER2 and blank (Current Ratio) and the best reproducibility in terms of $\mathrm{CV} \%$. In the case of the experiments for the optimisation of the secondary $\mathrm{Ab}$ concentration, best current ratio was obtained with $0.5 \mathrm{mg} \mathrm{L}-1$ of Ab with very poor reproducibility (19\%): in this case, the chosen parameter was the $1 \mathrm{mg} \mathrm{L}-1$ concentration of Ab for the acceptable Current Ratio (1.6) and the very good reproducibility $(\mathrm{CV} \%=3 \%)$.

The chosen parameters were: primary Ab 100 mg L-1; secondary Ab 1 mg L-1 and 30 min; antigen $1 \mathrm{~h}$.

\begin{tabular}{|c|c|c|}
\hline & $\begin{array}{c}\text { Average } \\
\text { CV\% }\end{array}$ & $\begin{array}{c}\text { Current Ratio } \\
\text { Signal }\left(10 \mathrm{ng} \mathrm{mL}^{-1}\right) / \text { Blank }\left(0 \mathrm{ng} \mathrm{mL}^{-1}\right)\end{array}$ \\
\hline Primary Ab 50 mg L-1 & $25 \%$ & 1.7 \\
\hline Primary Ab 100 mg L-1 & $10 \%$ & 1.4 \\
\hline Antigen incubation time $30 \mathrm{~min}$ & $6 \%$ & 1.8 \\
\hline Antigen incubation time $1 \mathrm{~h}$ & $2 \%$ & 2.3 \\
\hline Secondary Ab 0.5 mg L-1 & $19 \%$ & 4.2 \\
\hline Secondary Ab 1 mg L-1 & $3 \%$ & 1.6 \\
\hline
\end{tabular}




\begin{tabular}{|l|l|l|}
\hline & & \\
\hline Secondary Ab incubation time 30 min & $10 \%$ & 2.1 \\
\hline Secondary Ab incubation time $\mathbf{1}$ h & $11 \%$ & 1.4 \\
\hline
\end{tabular}

Table 1. Optimisation of the assay parameters primary Ab concentration, antigen incubation time, secondary $\mathrm{Ab}$ concentration and incubation time. First column: parameter; second column: average $\mathrm{CV} \%$ for two concentrations of HER2 $\left(0\right.$ and $\left.10 \mathrm{ng} \mathrm{mL}^{-1}\right)$ for each examined parameter; current ratio among the current recorded for the blank and for $10 \mathrm{ng} \mathrm{mL}^{-1}$ of HER2.

\subsection{Optimisation of blocking agents}

Blocking agents were used at two different steps of the sandwich assay: after beads functionalisation in order to saturate all the protein A binding sites and avoid binding of the secondary antibody to the beads. Moreover, during the incubation of the enzyme different blocking agents were used in order to prevent non specific adsorption of the enzyme onto the beads. In order to assess the effectiveness of this treatment, after the functionalisation procedure, experiments were conducted to determine the effects that the addition of rabbit IgG solutions at different concentrations would have on the signal produced when $0 \mathrm{ng} \mathrm{mL}{ }^{-1}$ and $10 \mathrm{ng} \mathrm{mL}^{-1}$ of HER2 were used in the assay. After the realisation of the complete assay, electrochemical measurements were carried out. Rabbit IgG was incubated with anti-HER2 primary antibody-functionalised beads at 0 , 1, 5 and $10 \mathrm{mg} \mathrm{L-1}$ concentration. No difference was observed when using $1 \mathrm{mg} \mathrm{L}-1$ of rabbit $\operatorname{IgG}$, whereas increased signal/blank ratio was obtained with 5 and $10 \mathrm{mg} \mathrm{L}-1$ of rabbit IgG (2 and 5 fold signal of $10 \mathrm{ng} \mathrm{mL}^{-1}$ HER2 with respect to blank, respectively). In the light of these results, blocking of functionalised beads with $10 \mathrm{mg} \mathrm{L-1}$ of rabbit IgG was chosen for further experiments. The blocking agent in the enzyme, alkaline phosphatase, incubation buffer (buffer G) was further optimised. Casein and BSA were added to this buffer and measurements were carried out as previously described. The results are reported in Figure 1a. Better results were obtained with BSA in terms of reproducibility $(\mathrm{CV} \%=7 \%)$. In order to improve the ratio between the blank signal and the signal of HER2, BSA was tested at two concentrations in buffer G, 0.5 and $1 \%$ (Figure $1 b$ ). With BSA at $1 \%$ concentration a five times higher signal was obtained with HER2 with respect to the blank signal with a good reproducibility $(\mathrm{CV} \%=9 \%)$. 

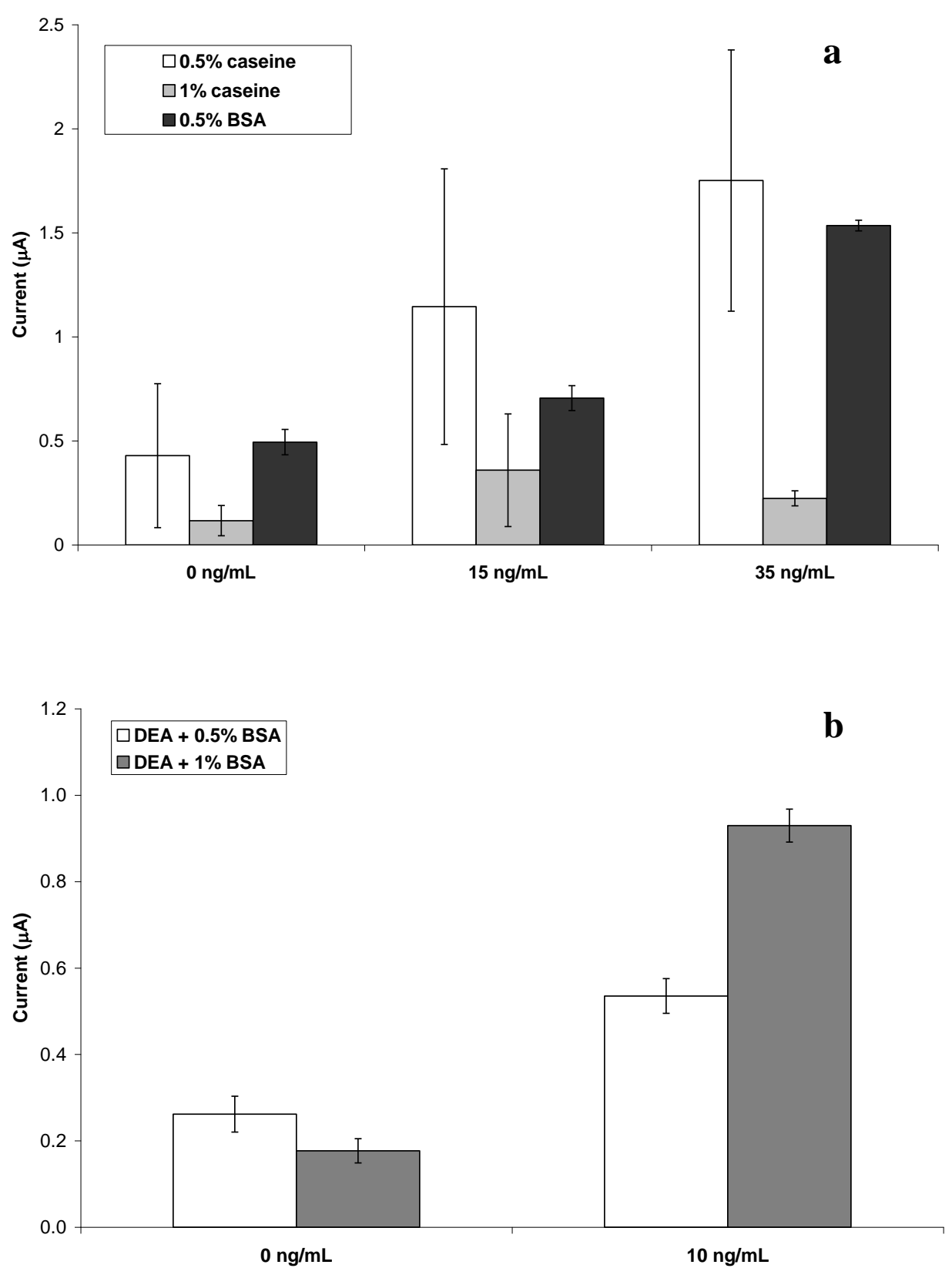

Figure 1: Optimisation of the blocking agent during the incubation of the enzyme. a) Optimisation of the blocking agent: casein or BSA were added to buffer $\mathrm{G}$ for the incubation of the streptavidinalkaline phosphatase conjugate. b) Optimisation of BSA concentration: $0.5 \%$ and $1 \%$ BSA was added to buffer $\mathrm{G}$ for the incubation of the streptavidin-alkaline phosphatase conjugate.

\subsection{Calibration curve of HER2 using a dual antibody sandwich assay}

A calibration curve under the conditions optimised for HER2 was performed. For this purpose, a screen-printed cell was used to test a different HER2 concentration. The calibration curve in the concentration range $0-30 \mathrm{ng} \mathrm{mL}^{-1}$ was performed: a linear range $\left(\mathrm{y}=9.0 * 10^{-8} \mathrm{x}+1.6 * 10^{-6}, \mathrm{R}^{2}=\right.$ 0.997) covers the HER2 concentration range $0-15 \mathrm{ng} \mathrm{mL} \mathrm{m}^{-1}$, which is also the important concentration range from the clinical point of view. 
An average $\mathrm{CV} \%$ of $7 \%$ was obtained by repeating the experiment using different electrodes $(\mathrm{n}=5)$. The detection limit, calculated by interpolating the mean of the blank solution response plus three times its standard deviation in the linear equation, was determined as $6 \mathrm{ng} \mathrm{mL}{ }^{-1}$, which can be considered adequate to the threshold value of $15 \mathrm{ng} \mathrm{mL}^{-1}$, for the possible application to real samples analysis.

\subsection{Serum samples analysis}

Once verified the suitability of the assay to detect HER2 in standard solutions, experiments on serum samples were carried out. Initial experiments concerned commercial serum spiked with HER2 at a known concentration. HER2 was added to serum either not treated or after filtration $(0.45 \mu \mathrm{m})$. Results are reported in Figure 2.

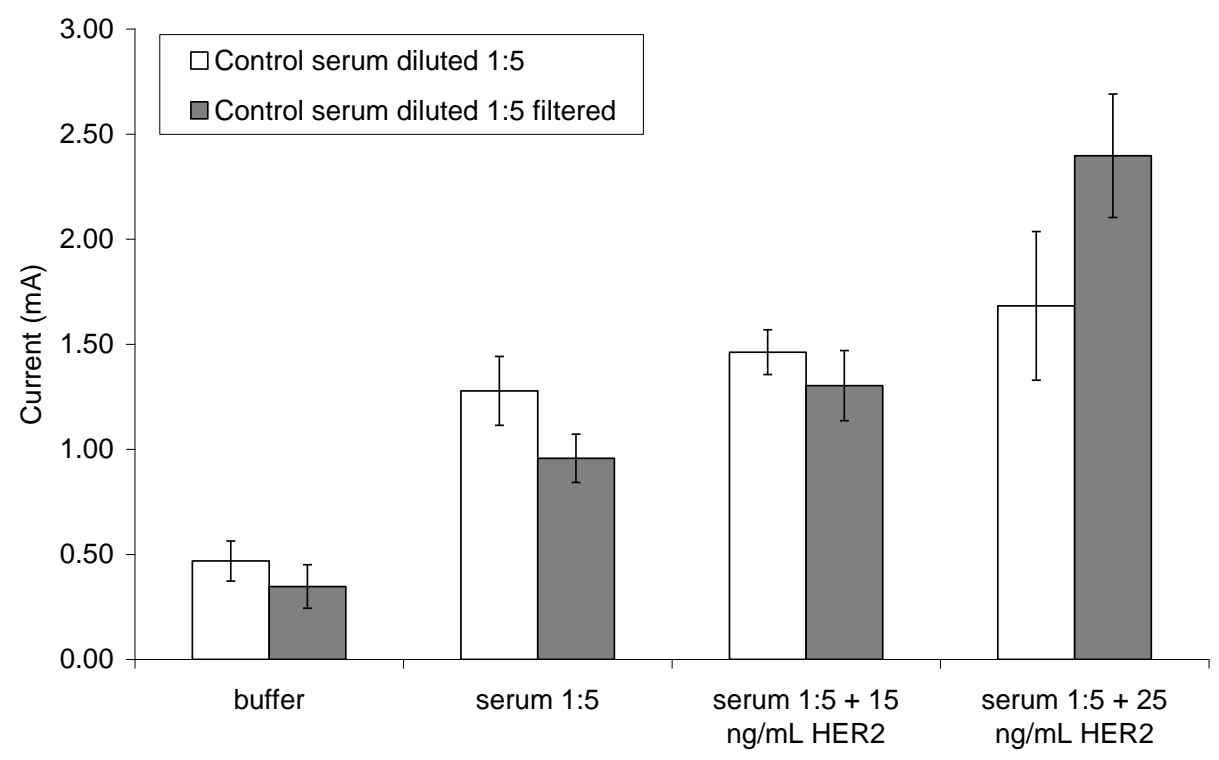

Figure 2: Experiments with commercial serum 1:5 in buffer, filtered and not filtered and spiked with 15 and $25 \mathrm{ng} \mathrm{mL}^{-1}$ HER2.

Increasing current signals were obtained both with spiked serum, filtered and non treated, but better discrimination between serum alone and different concentrations of HER2 were obtained with filtered serum. This is probably due to some matrix effect of the complex serum mixture on the measurement or to less availability of HER2 in the non-filtered serum. Good reproducibility in terms of CV\% was achieved with both kinds of serum samples (average CV\% 10\%).

Real serum samples were then analysed. The samples were from hospital patients who have been subjected to breast mass analysis: breast tissue samples were subjected to full histological diagnosis and DNA extraction for multiplex PCR testing. All the samples were from patient suffering from breast carcinoma, but from the histological analysis, samples 3,8 and 9 resulted not to be 
metastasized, whereas samples 5 and 7 have advanced malignancy (at end stage). All the other samples $(1,2,4,6)$ have lymph node metastasis.

The sandwich assay results are reported in Table 2. The concentration of HER2 cannot be quantified directly by comparison with a calibration curve due to different matrices between serum and buffer or sera from hospital and commercial serum, but a qualitative correlation between level of signal and malignancy stage can be done. Actually, from the sandwich assay analysis, samples with metastasis at the end stage (samples 5 and 7) could be detected and differentiated from the ones without metastasis or with lymph node metastasis. Since HER2 is actually considered as a prognostic marker for breast cancer, the proposed sandwich assay demonstrated to be a useful test to screen samples for a prognostic evaluation.

\begin{tabular}{cclcc}
\hline Sample number & Age & Histological diagnosis & Grading & $\begin{array}{c}\text { Immunoassay } \\
\text { results } \\
\text { Current }(\mu \mathbf{A})\end{array}$ \\
\hline $\mathbf{1}$ & 68 & Infiltrating ductal carcinoma & 2 & $0.20 \pm 0.04$ \\
\hline $\mathbf{2}$ & 58 & Infiltrating ductal carcinoma & 3 & $0.16 \pm 0.01$ \\
\hline $\mathbf{3}$ & 53 & Infiltrating ductal carcinoma & 3 & $0.20 \pm 0.06$ \\
\hline $\mathbf{4}$ & 55 & Lobular carcinoma & 3 & $0.23 \pm 0.03$ \\
\hline $\mathbf{5}$ & 35 & Infiltrating ductal carcinoma & 3 & $2.5 \pm 0.2$ \\
\hline $\mathbf{6}$ & 62 & Ductal carcinoma in situ & 3 & $0.19 \pm 0.05$ \\
\hline $\mathbf{7}$ & 55 & Infiltrating ductal carcinoma & 3 & $7.3 \pm 1.6$ \\
\hline $\mathbf{8}$ & 35 & Infiltrating ductal carcinoma & 2 & $0.20 \pm 0.01$ \\
\hline $\mathbf{9}$ & 61 & Infiltrating ductal carcinoma & 2 & $0.15 \pm 0.01$ \\
\hline
\end{tabular}

Table 2. Results obtained with real serum samples. First column: sample number; second column: age of the patient; third column: type of cancer resulting from the histological diagnosis; fourth column: grade of cancer; fifth column: immunoassay results expressed as current recorded after the analysis of the serum sample \pm the standard deviation $(n=3)$. Evidenced in grey are the two samples (5 and 7) with metastasis at the end stage and which resulted in a higher current signal from the immunoassay analysis.

\section{Conclusions}

A simple and sensitive approach for HER2 detection is described, by using antibody modified paramagnetic microparticles coupled to electrochemical platform for electrochemical revelation using alkaline phosphatase as enzyme label and signal amplification. 
The different parameters of the assay were optimised and a first calibration was produced in buffered solution with good sensitivity $\left(6 \mathrm{ng} \mathrm{mL}^{-1}\right)$ and reproducibility (average $\mathrm{CV} \%=7 \%$ ) were obtained for HER2 detection, with a linear response which matches clinical needs.

The sensitivity achieved was adequate for the analysis of serum samples, since $15 \mathrm{ng} \mathrm{mL} \mathrm{mas}^{-1}$ was defined as the appropriate cut-off between normal and elevated serum HER-2 protein levels. The immunoassay was also tested on serum samples, yielding promising results for use with real samples. 


\section{References}

1. Cayre, A., Mishellany, F., Lagarde, N. and Penault-Llorca, F. (2007) Comparison of different commercial kits for HER2 testing in breast cancer: looking for the accurate cutoff for amplification, Breast Cancer Research, 9, R64, doi:10.1186/bcr1770.

2. Colombo, M., Corsi, F., Foschi, D., Mazzantini, E., Mazzucchelli, S., Morasso, C., Occhipinti, E., Polito, L., Prosperia, D., Ronchi, S. and Verderio, P. (2010) HER2 targeting as a two-sided strategy for breast cancer diagnosis and treatment: outlook and recent implications in nanomedical approaches, Pharmacological Research, doi:10.1016/j.phrs.2010.01.013 (article in print).

3. Esteva, F.J., Cheli, C.D., Fritsche, H., Fornier, M., Slamon, D., Thiel, R.P., Luftner D. and Ghani, F. (2005) Clinical utility of serum HER2/neu in monitoring and prediction of progression-free survival in metastatic breast cancer patients treated with trastuzumab-based therapies, Breast Cancer Research, 7, R436-R443, doi:10.1186/bcr1020.

4. Gohring, J.T., Dale, P.S. and Fan, X. (2010) Detection of HER2 breast cancer biomarker using the opto-fluidic ring resonator biosensor, Sensors and Actuators B, 146, 226-30.

5. Lottner, C., Schwarz, S., Diermeier, S., Hartmann, A., Knuechel, R., Hofstaedter F. and Brockhoff, G. (2005) Simultaneous detection of HER2/neu gene amplification and protein overexpression in paraffin-embedded breast cancer, Journal of Pathology, 205, 577-84.

6. Ludovini, V., Gori, S., Colozza, M., Pistola, L., Rulli, E., Floriani, I., Pacifico, E., Tofanetti, F.R., Sidoni, A., Basurto, C., Rulli, A. and Crino, L. (2008) Evaluation of serum HER2 extracellular domain in early breast cancer patients: correlation with clinicopathological parameters and survival, Annals of Oncology, doi:10.1093/annonc/mdm585.

7. Payne, R.C., Allard, J.W., Anderson-Mauser, L., Humphreys, J.D., Tenney, D.Y and Morris, D.L. (2000) Automated assay for HER-2/neu in serum, Clinical Chemistry, 46, 2 , 175-82.

8. Quaranta, M., Daniele, A., Coviello, M., Savonarola, A., Abbate, I., Venneri, M.T., Paradiso, A., Stea, B., Zito, A., Labriola, A. and Schittulli, F. (2006) c-erbB-2 protein level in tissue and sera of breast cancer patients: a possibly useful clinical correlation, Tumori, 92, $311-7$.

9. Streckfus, C., Bigler, L., Dellinger, T., Dai, X., Kingman, A. and Thigpen, J.T. (2000) The presence of soluble c-erbB-2 in saliva and serum among women with breast carcinoma: a preliminary study, Clinical Cancer Research, 6, 2363-70. 
10. Tse, C., Brault, D., Gligorov, J., Antoine, M., Neumann, R., Lotz, J-P. and Capeau, J. (2005) Evaluation of the quantitative analytical methods real-time PCR for HER-2 gene quantification and ELISA of serum HER-2 protein and comparison with fluorescence in situ hybridization and immunohistochemistry for determining HER-2 status in breast cancer patients, Clinical Chemistry, 51, 7, 1093-101. 